\title{
CULTURAL EXTENSION OF TAXODIUM IN THE TERRITORY OF SLOVAKIA AND ITS GENETIC-GENOMICAL NOTES
}

\author{
Mňahončáková Erika ${ }^{1 *}$, Ražná Katarína ${ }^{2}$, Hrubík Pavel ${ }^{3}$ \\ ${ }^{1}$ Botanic garden, Slovak University of Agriculture in Nitra, Tr. Andreja Hlinku 2, 94976 Nitra, Slovakia \\ ${ }^{2}$ Department of Genetics and Plant Breeding, Faculty of Agrobiology and Food Resources, Slovak University \\ of Agriculture in Nitra, Slovakia \\ ${ }^{3}$ Emeritus professor, Dunajská 16, 94911 Nitra, Slovakia
}

\section{KULTÚRNE ROZŠÍRENIE RODU TAXODIUM NA ÚZEMÍ SLOVENSKA A JEHO GENETICKO-GENOMICKÉ POZNATKY}

\author{
Mňahončáková Erika, Ražná Katarína, Hrubík Pavel \\ Received 25. 6. 2017 \\ Revised 29.6. 2017 \\ Published 29. 11. 2017
}

\begin{abstract}
The subject of the research was to find out the cultural expansion of two species of Taxodium, namely Taxodium ascendens (Brongn.) and Taxodium distichum (L.) L. C. Rich. The occurrence of individuals was recorded on 18 different localities of Slovakia, obtaining the taxonomic-dendrometric characteristics of individual trees. Appropriate methodologies and available devices have been used. Biological data, such as tree planting, health status, landscaping value, and tree age were recorded. The Taxodium distichum (L.) L. C. Rich. is found in 15 localities in Slovakia and in the three localities of Taxodium ascendens (Brongn.). Regarding the number of trees represented, Taxodium distichum contains 35 trees growing on individual localities, of which 3 are state-protected trees. We did not confirm 9 trees at registered locations. In general, we have seen a declining level of maintenance and care for our historic parks and state-protected trees. Literary records characterizing the genome of these rare species are focused on the study of genetic variability and polymorphism mapping using various types of molecular markers to elucidate the genetic essence of phenotypic variability and the historical structure of species populations.
\end{abstract}

Keywords: Taxodium distichum; Taxodium ascendens; taxonomic-dendrometric; characteristics

\section{Úvod}

Druh Taxodium je známy svojou významnou toleranciou voči stresu zavodnenia, z čoho vyplýva jeho vel'ký ekologický a ekonomický potenciál (Qi et al., 2014). Taxodium, patrí do čelade Taxodiaceae tisovcovité (Mareček et al., 2001). Známe sú tri druhy, ktorých domovom sú južné oblasti Severnej Ameriky a Mexika, väčšinou na bažinách alebo velmi mokrých pôdach (Hieke, 2008). Uvádzame dva druhy: Taxodium ascendens (Brongn.) a Taxodium distichum (L.) L. C. Rich., ktoré boli predmetom výskumu a merania na Slovensku.

Tisovec potrebuje v mladosti polotieň, neskôr svetlé stanovište. V našich podmienkach je odolný voči zime, nie je príliš náročný na pôdu, ideálna je teplejšia, piesočnato hlinitá, dobre priepustná a hlavne

*Corresponding author: Erika Mňahončáková, Botanic garden, Slovak University of Agriculture in Nitra, Tr. Andreja Hlinku 2, 94976 Nitra, Slovakia, $\bowtie$ erika.mnahoncakova@gmail.com 
dostatočne vlhká až mokrá pôda. Môže sa pestovat’ v bažinatom teréne, prípadne i v priechodne plytkých stojatých vodách. Na suchých stanovištiach zakrpatieva, koruny sú preschnuté a riedke. Neznáša zatienenie, znečistené ovzdušie znáša dobre (Hieke, 2008; Mareček et al., 2001).

Napriek výraznému ekologickému a ekonomickému potenciálu, genomické informácie tohto druhu sú limitované, čo značne spomaluje tvorbu molekulových markérov a d’alšie poznávanie mechanizmov tolerancie daného druhu voči podmienkam zamokrenia (Qi et al., 2014).

\section{Materiál a metódy}

Prieskum na všetkých evidovaných lokalitách sme absolvovali osobnou účast’ou autorov publikácie, preto môžeme zodpovedne konštatovat’ znižujúcu sa úroveň údržby a starostlivosti o naše historické parky a štátom chránené stromy (označenie stromov je však viac rešpektované). Pre zlepšenie súčasného stavu odporúčame rozšírit zoznam štátom chránených stromov, ako aj niektorých významnejších historických parkov.

Pri našom výskume sme použili osvedčené metodické pracovné postupy a dostupné prístroje a iné pomôcky: výškomer SUUNTO, textilné pásmo s prepočtom cm obvodu kmeňa na jednej strane, na $\mathrm{cm}$ priemeru kmeňa na opačnej strane; d’alej sme merali šírku koruny stromu, ako priemet koruny na zem v dvoch smeroch; výška stromu v m; iné biologické údaje: plodenie stromu, zdravotný stav a sadovnícka hodnota; vek stromu - výpočtom podla matematického vzorca; podla roku introdukcie dreviny na Slovensko, prípadne do Európy; odhadom podla celkových rozmerov stromu. Od zistovania veku pomocou vývrtov z Presslerovho vrtáka, sme pre následnú finančnú náročnost' upustili. Zistovanie veku stromov považujeme za metodicky najobtažnejšie, preto sa nevyhneme ani využitiu publikovaných údajov o prvej introdukcii dreviny na územie Slovenska.

Základné dendrometrické hodnoty namerané na jednotlivých stromoch vybranej skupiny drevín sú spracované v tabul'kovom prehl'ade.

\section{Výsledky a diskusia}

Kultúrne rozšírenie dvoch vybraných druhov cudzokrajných drevín, zriedkavo na Slovensku pestovaných, sme zaznamenali na 18 rôznych lokalitách (historické parky, botanické záhrady, arboréta, kategórie ostatnej vegetácie v urbanizovanom prostredí, ako aj pokusné plochy v lesných porastoch). Medzi nimi je aj štátom chránený strom tisovca dvojradového. Medzi najkomplexnejšie publikácie opisujúce rozšírenie uvedených drevín na Slovensku patria práce autorov: Benčat' (1982), Holubčík (1968).

Zastúpenie na Slovensku má tisovec dvojradový - 15 lokalít (Tabul'ka 1) a tisovec vystúpavý - 3 lokality (Tabul'ka 2).

Z hladiska početnosti zastúpenia evidovaných stromov sa Taxodium distichum vyskytuje 35 stromov, rastúcich na jednotlivých lokalitách, z toho 3 štátom chránené stromy. Pritom 9 stromov sme na evidovaných lokalitách nepotvrdili.

Vel'kost' genómu tisovca dvojradového je viac ako trojnásobne väčšia v porovnaní s genómom človeka, avšak obsah DNA (1C) patrí medzi jeden z najmenších v rámci ihličnatých druhov (Liu et al., 2011). Vel'kost' jeho genómu je $9731 \mathrm{Mb}$. Je to diploidný druh s počtom chromozómov 2n = 2x = 22 . Genomickou analýzou sa zistilo, že 90 \% genómu tisovca je tvorené opakujúcimi sa sekvenciami DNA (repetetívna DNA). Väčšina týchto sekvencií je zastúpená nízkymi a strednými počtami kópií v genóme. 
Tabulka 1 Taxačno-dendrometrické charakteristiky stromov Taxodium distichum (L.) L.C. Rich. (pestovanie na Slovensku: 1842 - 2016, maximum 174 rokov)

Table 1 Taxonomic-dendrometric characteristics of Taxodium distichum (L.) L.C. Rich. Trees (cultivated in Slovakia during years 1842-2016, 174 years maximum)

\begin{tabular}{|c|c|c|c|c|c|c|}
\hline Lokalita & $\begin{array}{c}\text { Obvod } \\
\text { kmeňa, cm }\end{array}$ & $\begin{array}{c}\text { Priemer } \\
\text { kmeňa, cm }\end{array}$ & $\begin{array}{c}\text { Výška } \\
\text { stromu, m }\end{array}$ & $\begin{array}{c}\text { Šírka koruny, } \\
\text { m }\end{array}$ & $\begin{array}{c}\text { Plodenie } \\
(+/-)\end{array}$ & Vek \\
\hline Arborétum Mlyňany SAV & 253 & 80,6 & 32 & $12 \times 12$ & + & 98 \\
\hline Arborétum Mlyňany P45 & $232 ; 234$ & 73,$8 ; 74,6$ & 27 & $8 \times 8$ & & 120 \\
\hline \multirow{6}{*}{ Bratislava, BZ PFUK } & 234 & 74,6 & 20 & $12 \times 12$ & + & 94 \\
\hline & 156 & 49,6 & 22 & $7 \times 7$ & + & 62 \\
\hline & 90 & 28,7 & 16 & $5 \times 5$ & + & 36 \\
\hline & $233 ; 243$ & 74,$3 ; 77,3$ & $25 ; 27$ & $10 \times 6 ; 12 \times 12$ & ++ & 97 \\
\hline & 208 & 66,2 & 24 & $8 \times 6$ & + & 83 \\
\hline & 170 & 54,6 & 20 & $10 \times 6$ & + & 68 \\
\hline \multirow{3}{*}{ Janova Ves } & 308 & 98,4 & 27 & $12 \times 10$ & + & 122 \\
\hline & 300 & 95,9 & 18 & $10 \times 10$ & + & 120 \\
\hline & 183 & 58,3 & 12 & $10 \times 10$ & + & 120 \\
\hline Krupina, CVČ DOMČEK & 407 & 130,0 & 22 & $18 \times 15$ & + & 162 \\
\hline Malacky, Mestský park & 251 & 80,0 & 24 & $17 \times 17$ & + & 100 \\
\hline Nitra, BZ SPU & 20 & 6,4 & 3 & $1 \times 1$ & - & 20 \\
\hline \multirow{9}{*}{ Tomášikovo } & 445 & 142,1 & 32 & $16 \times 16$ & + & 170 \\
\hline & 382 & 122,0 & 32 & $14 \times 14$ & + & 170 \\
\hline & 386 & 123,3 & 32 & $10 \times 10$ & + & 170 \\
\hline & 425 & 135,7 & 32 & $12 \times 12$ & + & 170 \\
\hline & 360 & 115,0 & 32 & $12 \times 12$ & + & 170 \\
\hline & 345 & 110,2 & 32 & $12 \times 12$ & + & 170 \\
\hline & 306 & 97,8 & 30 & $10 \times 10$ & + & 170 \\
\hline & 415 & 132,5 & 34 & $14 \times 14$ & + & 170 \\
\hline & 420 & 134,1 & 34 & $14 \times 14$ & + & 170 \\
\hline \multirow{5}{*}{ Topol'čianky, Park ŠL } & 450 & 143,7 & 25 & $17 \times 17$ & + & 170 \\
\hline & 370 & 118,3 & 25 & $14 \times 14$ & + & 148 \\
\hline & 274 & 87,3 & 27 & $16 \times 16$ & + & 148 \\
\hline & 320 & 102,3 & 29 & $15 \times 15$ & + & 148 \\
\hline & 315 & 100,7 & 25 & $12 \times 12$ & - & 148 \\
\hline Tovarníky, Park Ocú & 460 & 146,9 & 25 & $15 \times 15$ & + & 170 \\
\hline
\end{tabular}


Pokračovanie tabulky 1

Continuation of Table 1

\begin{tabular}{|l|c|c|c|c|c|c|}
\hline Lokalita & $\begin{array}{c}\text { Obvod } \\
\text { kmeňa, cm }\end{array}$ & $\begin{array}{c}\text { Priemer } \\
\text { kmeňa, cm }\end{array}$ & $\begin{array}{c}\text { Výška } \\
\text { stromu, m }\end{array}$ & $\begin{array}{c}\text { Šírka koruny, } \\
\mathbf{~ m}\end{array}$ & $\begin{array}{c}\text { Plodenie } \\
(+/-)\end{array}$ & Vek \\
\hline \multirow{2}{*}{ Trenčianske Teplice } & 520 & 165,9 & 18 & $14 \times 14$ & + & 170 \\
\hline \multirow{3}{*}{ Bernolákovo, hist. park } & 289 & 89,7 & 24 & $10 \times 10$ & + & 145 \\
\cline { 2 - 7 } & 243 & 77,6 & 24 & $10 \times 10$ & + & 145 \\
\cline { 2 - 7 } & 282 & 90,1 & 22 & $8 \times 8$ & + & 145 \\
\cline { 2 - 7 } & 333 & 106,4 & 26 & $10 \times 10$ & + & 145 \\
\hline \multirow{2}{*}{ Rakovice, hist. park SOZŠ } & 312 & 99,7 & 25 & $11 \times 11$ & + & 120 \\
\cline { 2 - 7 } & 328 & 104,8 & 35 & $12 \times 12$ & + & 120 \\
\hline \multirow{2}{*}{ Želiezovce, Mestský park } & 394 & 125,8 & 23 & $18 \times 17$ & + & 158 \\
\cline { 2 - 7 } & 510 & 162,8 & 27 & $18 \times 20$ & + & 174 \\
\hline
\end{tabular}

Tabulka 2 Taxačno-dendrometrické charakteristiky stromov Taxodium ascendens (L.) L.C. Rich.

Table 2 Taxonomic-dendrometric characteristics of Taxodium ascendens (L.) L.C. Rich. trees.

\begin{tabular}{|l|c|c|c|c|c|c|}
\hline Lokalita & $\begin{array}{c}\text { Obvod } \\
\text { kmeňa, cm }\end{array}$ & $\begin{array}{c}\text { Priemer } \\
\text { kmeňa, cm }\end{array}$ & $\begin{array}{c}\text { Výška } \\
\text { stromu, m }\end{array}$ & $\begin{array}{c}\text { Š́rka } \\
\text { koruny, m }\end{array}$ & $\begin{array}{c}\text { Plodenie } \\
\text { (+/-) }\end{array}$ & Vek \\
\hline Bratislava, BZ PFUK & 17 & 5,5 & 5 & $2 \times 2$ & - & 20 \\
\hline Nitra, BZ SPU & 10 & 3,5 & 2 & $1 \times 1$ & - & 20 \\
\hline Arborétum Mlyňany P-35 & 20 & 6,4 & 6 & $3 \times 3$ & - & 40 \\
\hline
\end{tabular}

Štúdie prirodzenej genetickej variability umožňujú objasnit’ genetickú podstatu fenotypovej variability a historickú štruktúru populácie druhu (Ikezaki et al., 2016). Autori sledovali morfologické a ekologické rozdiely medzi Taxodium distichum var. distichum a Taxodium distichum var. imbricarium pomocou vysoko výkonnej DNA sekvenácie. Stupeň genetických rozdielov medzi týmito dvomi varietami bol nízky, ale štatisticky významný. Prítomnost’ niektorých lokusov poukazovala na aplikáciu pozitívnej selekcie jedincov, čoho dôsledkom je rôzna adaptability druhu na miestne environmentálne podmienky. Z výsledkov vyplýva, že testované jedince Taxodium distichum var. distichum boli geneticky rozdelené na dve geografické skupiny. Odhadované demografické parametre poukazujú na to, Taxodium distichum var. imbricarium bol odčlenený od Taxodium distichum var. distichum počas obdobia miocénu.

Tisovec patrí medzi druhy, ktoré sa vyznačujú vysokou vysokými nárokmi na vlhkost'. Pre účely zalesňovania pobrežných a zamokrených oblastí na juhovýchode Číny, bolo vytvorených viacero vnútro druhových krížencov.

Druhy Taxodium distichum a Taxodium ascendes boli súčastou výskumu v rámci reliktných druhov, z hl'adiska charakterizácie evolúcie génov MYB, kódujúcich jednu z najväčších skupín transkripčných faktorov, ktoré sa podielajú na obranných mechanizmoch rastlín (Lu et al., 2014).

Poznatky o genetickej variabilite drevín sú základom pre udržatelný lesný manažment (Popović et al., 2015). Aj napriek významnému ekologickému a ekonomickému potenciálu druhu Taxodium, sú 
informácie ohladne genómu týchto druhov nedostatočné, čo má vplyv na d’alší výskum a tvorbu molekulových markérov.

Významnost’ a dôležitost' aplikácie molekulových markérov vo výskume drevín potvrdzuje aj práca autorov Tsumura et al. (1999). Dva taxóny druhu tisovca, Taxodium distichum var. distichum a Taxodium distichum var. imbricarium boli charakterizované pomocou CAPS markérov (Cleaved Amplified polymorphic Sequence, markéry dížkového polymorfizmu reštrikčne štiepenej zmnoženej DNA). Niektorí autori uvádzajú druh tisovec vystúpavý (Taxodium ascendens Brongn.) ako odlišný druh, zatial' čo iní ho uvádzajú ako varietu/ekotyp (Taxodium distichum var. imbricarium (Nutt.) Croom). V danej štúdii bola genetická variabilita spomínaných dvoch taxónov analyzovaná použitím 10 DNA markérov na báze sekvencií cDNA z klonov Cryptomeria japonica, ako príbuzného druhu tisovca. CAPS kodominantné markéry nenaznačili, že Taxodium distichum var. imbricarium je odlišný druh od Taxodium distichum var. distichum. Uvedení autori navrhujú pre tieto dva taxóny označenie ako varietu.

Jedným z najrozšírenejších typov molekulových markérov sú RAPD (Random Amplified Polymorphic DNA, polymorfizmus náhodne zmnoženej DNA). V prípade Taxodium distichum L. RICH. bolo na posúdenie genetickej variability 20 jedincov použitých 13 RAPD prajmerov. Na základe získaných hodnôt koeficienta podobnosti bola vytvorená zhluková analýza. Dvadsat' jedincov bolo rozdelených do dvoch podzhlukov, poukazujúc na prítomnost’ výraznej genetickej variability v rámci daného druhu (Popović et al. 2015). Snahou autorov Lu et al. (2013) bolo vytvorenie takej markérovacej techniky, ktorá by aj napriek nepostačujúcemu množstvu dostupných genomických údajov umožňovala charakterizovat' 10 druhov siedmich rodov čelade Taxodiaceae. Amplifikácia spoločných konzervovaných oblastí kódujúcich sekvencií označovaná ako ACGM (Amplified Consensus Genetic Marker) technika je aplikovatel'ná pre tvorbu markérov aj pri druhoch s obmedzenou dostupnostou genomických údajov.

Ďalší typ markérov na báze exprimovaných sekvencií (EST, Expressed Sequence Tag) bol vytvorený na základe dostupných údajov sekvenácie transkriptómu genómu klonu tisovca 'Zhongshansa 406' (Chen et al., 2015). V genóme bolo analyzovaných 108692 EST sekvencií s celkovou vel'kostou 69,3 Mb, v rámci ktorých sa identifikovalo 10038 jednoduchých opakujúcich sa poradí nukleotidov (SSR, Simple Sequence Repeats). Priemerný výskyt SSR lokusov v transkriptóme bol jeden na 6,90 kb exprimovaných sekvencií. Najviac zastúpenou skupinou opakujúcich sa sekvencií tvorili jednonukleotidové sekvencie $(65,56 \%)$, následne trinukleotidové $(22,37 \%)$ a dinukleotidové (10,76 \%). Pre vytvorenie SSR markérov boli vybraných 1958 EST-SSR lokusov a následne boli tieto SSR markéry overené návrhom 503 párov prajmerov. Viac ako $50 \%$ z nich umožnilo amplifikáciu požadovaných produktov. Funkčná kategorizácia EST sekvencií potvrdila takmer 53 \% homológiu so známymi bielkovinami. Skupina vytvorených EST-SSR markérov poskytuje hodnotný genetický a genomický nástroj pre d’alší genetický výskum druhu Taxodium.

Z uvedeného prehladu je zrejmé, že problematika zaoberajúca sa molekulárnym výskumom týchto vzácnych drevín siaha do obdobia ostatných piatych rokov. Práve vd’aka súčasným moderným výskumným metódam, ku ktorým patrí aj sekvenácia genómu, a prístrojovej infraštruktúre, bude možné výrazne obohatit’ bioinformačné databázy o dôležité informácie pre účely ochrany a manažmentu vzácnych genetických zdrojov drevín. 


\section{Závery}

Na základe poznatkov z nášho terénneho výskumu kultúrneho rozšírenia vybraných zriedkavo pestovaných cudzokrajných stromov, konštatujeme, že na Slovensku disponujeme vzácnym fytogenofondom cudzokrajných drevín, ktorý je potrebné chránit', zvel'ad'ovat' a propagovat'.

\section{Literatúra}

Benčat', F. 1982. Atlas rozšírenia cudzokrajných drevín a rajonizácia ich pestovania na Slovensku. Bratislava: VEDA, vydavatel'stvo SAV. 451 s. (mapy), 359 s.

Hieke, K. 2008. Encyklopedie jehličnatých stromů a keřu. Computer Press a.s. 246 s. ISBN 978-80-251-1901-3.

Holubčík, M. 1968. Cudzokrajné dreviny v lesnom hospodárstve. Bratislava : Slovenské vydavatel'stvo pôdohospodárskej literatúry, $371 \mathrm{~s}$.

Ikezaki, Y., Suyama, Y., Middleton, B. et al. 2016. Inferences of population structure and demographic history for Taxodium distichum, a coniferous tree in North America, based on amplicon sequencing analysis. American Journal of Botany, vol. 103, no. 11, p. 1937-1949.

Lu, Y.-Q., Jia, Q., Tong, Z.-K. 2013. Development of amplified consensus genetic markers in Taxodiaceae based on Cryptomeria japonica ESTs data. Journal of Forestry Research, vol. 24, no. 3, p. 503-508.

Lu, Y.-Q., Jia, Q., Tong, Z.-K. 2014. Cloning and sequence analysis of nine novel MYB genes in Taxodiaceae plants. Journal of Forestry Research, vol. 25, no. 4, p. 795-804.

Mareček, F. et al. 2001. Záhradnícky slovník naučný 5. Praha : Ústav zemědělských a potravinářských informací. 685 s. ISBN 80-7271-075-3.

Murray, B.G. 1998. Nuclear DNA Amount in Gymnosperms. Annals of Botany, vol. 82, suppl. A, p. 3-15.

Popović, V., Lućić, A., Ristić, D., Rakonjac, L., Hadrović, S., Drinić Mladenović, S. 2015. analysis of intrapopulation variability of bald cypress Taxodium distichum I. rich.) in seed stand near Backa Palanka using RAPD markers. Genetika, vol. 47, no. 2, p. 571-580.

Tsumura, Y., Tomaru, N., Suyama, Y., Bacchus, S. 1999. Genetic diversity and differentiation of Taxodium in the south-eastern United States using cleaved amplified polymorfic sequences. Heredity, vol. 83, p. 229-238.

Qi, B., Yang, Y., Yin, Y., Xu, M., Li, H. 2014. De novo sequencing, assembly, and analyis of the Taxodium 'Zhongshansa'roots and shoots transcriptome in response to short-term waterlogging. BMC Plant Biology, vol. 14, no. 201. http://www.biomedcentral.com/1471-2229/14/201. 